\title{
Sistem Pakar Berbasis Web Menggunakan Metode Forward Chaining Untuk Mendiagnosa Penyakit Pulpa Dan Periapikal
}

\author{
Fadhilah $^{1}$, Irfan Mahendra ${ }^{2}$, Ilfa Khairina ${ }^{3}$ \\ Program Studi Sistem Informasi, STMIK Nusa Mandiri Jakarta ${ }^{1,2}$ \\ Program Studi Sarjana Keperawatan, Fakultas Keperawatan Universitas Andalas ${ }^{3}$ \\ fadhilahdilaf@gmail.com ${ }^{1}$,irfan.iha@nusamandiri.ac.id ${ }^{2}$ khairinailfa@gmail.com $^{3}$
}

\begin{abstract}
Abstrak
Penyakit pulpa dan periapikal banyak terjadi di Indonesia. Hal ini disebabkan karena pengetahuan dan kesadaran masyarakat mengenai kesehatan gigi yang masih rendah, sehingga tidak banyak masyarakat yang mengetahui tipe, gejala, serta solusi yang harus dilakukan terhadap penyakit yang dialaminya. Padahal sebenarnya penyakit pulpa dan periapikal dapat berdampak buruk terhadap kualitas hidup manusia. Selain itu biaya perawatan gigi juga tergolong mahaldan dapat berdampak pada kesehatan seseorang secara keseluruhan, seperti dapat menyebabkan penyakit yang sangat berbahaya seperti stroke, penyakit jantung, dan ginjal.Berdasarkan latar belakang tersebut, dipandang perlu untuk membuat sistem pakar berbasis web untuk mendiagnosa penyakit pulpa dan periapical dengan metode forward chaining. Sistem pakar ini dibuat menggunakan Dreamweaver CS6, PHP, CSS dan MySQL. Melalui aplikasi sistem pakar ini dapat membantu masyarakat dalam mendiagnosa penyakit pulpa dan periapikal dengan lebih mudah dan cepat, sehingga dapat ditangani dengan cepat dan tepat.
\end{abstract}

Kata kunci-sistem pakar, penyakit pulpa dan periapikal

\begin{abstract}
Pulp and periacal disease is happening in Indonesia. This is because knowledge and people awarness to take care their dental health is in low level, so that a few of people in Indonesia do not know types, symptoms, and the solution, how to resolve the problem. Altough pulp and periacal disease have a bad impact like the patient's quality of life. Besides the cost of expensive dental careand have an impact on a person's overall health, such as can cause catastrophic diseases such as stroke, heart desease, and kidney.Based on these conditions, very important to make a web-based expert system to diagnose this problem with forward chaining methode. The expert system is created using Dreamweaver C56, PHP, CSS, and MySQL. Through this system application, people will find out the information and get consultations about pulp and periapical disease easily and quickly, so that it can be dealt with quickly and correctly.
\end{abstract}

Keywords—expert system, pulp and periapical diseases

\section{PENDAHULUAN}

i dalam bidang kesehatan, banyak dikembangkan teknologi informasi yang dapat memberikan layanan yang bersifat personal terhadap masyarakat. Diantaranya yaitu sistem pakar yang dapat membantu masyarakat untuk mendiagnosa penyakit. Selain dapat 
membantu pekerjaan para medis, seperti dokter dan perawat, teknologi ini juga dapat mempermudah masyarakat untuk memperoleh informasi dan layanan kesehatan yang dibutuhkannya dengan lebih cepat. Apalagi dalam kehidupan yang sangat kompleks seperti saat ini, banyak orang yang merasa kesulitan untuk mendatangi fasilitas kesehatan untuk mendapatkan layanan yang dibutuhkannya.

Sakit gigi merupakan penyakit yang umum terjadi pada masyarakat di Indonesia. Penyakit gigi dan mulut menjadi penyakit tertinggi ke-6 yang dikeluhkan masyarakat Indonesia [1]. Berdasarkan data yang dirilis Pusat Data dan Informasi Kementerian Kesehatan RI pada tahun 2013, sebanyak 26\% penduduk Indonesia memiliki masalah gigi dan mulut [2]. Bahkan menurut Ketua Pengurus Besar PDGI, Dr. drg. Hananto Seno, Sp.BM., MM, merujuk pada Riset Kesehatan Dasar tahun 2013, angka kerusakan gigi di Indonesia mencapai 4-5 gigi per orang [3].

Salah satu jenis penyakit gigi yang banyak dialami masyarakat di Indonesia adalah penyakit pulpa dan periapikal. Di mana pada tahun 2010, penyakit pulpa dan periapikal terdapat pada urutan ke-7 penyakit rawat jalan di Indonesia [4].

Tingginya angka penderita penyakit gigi, khususnya penyakit pulpa dan periapikal ini, menjadi indikasi rendahnya pengetahuan dan kesadaran masyarakat mengenai kesehatan gigi. Padahal kalau dilihat dari dampak yang dapat ditimbulkan, sangat merugikan masyarakat. Selain biaya perawatannya yang mahal, kesehatan gigi juga dapat mempengaruhi kualitas hidup seseorang dan berdampak pada kesehatan seseorang secara keseluruhan, seperti dapat menyebabkan penyakit katastropik seperti stroke, jantung, dan ginjal.

Berdasarkan paparan di atas, guna meningkatkan pengetahuan masyarakat mengenai penyakit pulpa dan periapikal, dipandang perlu untuk melakukan penelitian lebih lanjut untuk membangun aplikasi sistem pakar berbasis web, yang tidak saja menyediakan informasi mengenai penyakit pulpa dan periapikal, namun juga dapat digunakan untuk mambantu masyarakat pengguna dalam mendiagnosa penyakit pulpa dan periapikal yang dialaminya. Penelitian ini sejalan dengan penelitian yang dilakukan oleh Nurzaman dkk [5], Nurlaela [6], dan penelitian Lukman [7].

\section{METODE PENELITIAN}

\subsection{Teknik Pengumpulan Data}

1. Observasi

Teknik pengumpulan data yang dilakukan dalam penelitian ini, sebagai berikut:

Observasi adalah teknik mendapatkan data primer dengan cara mengamati langsung obyek datanya [8]. Teknik pengumpulan data dengan observasi digunakan bila, penelitian berkenaan dengan perilaku manusia, proses kerja, gejala-gejala alam dan bila responden yang diamati tidak terlalu besar [9]. Pada penelitian ini, observasi dilakukan di Aziz Dental Clinic, Klinik drg. Adibah, dan Klinik Mydentist untuk mengamati secara langsung kegiatan yang dilakukan para pakar dalam menangani kasus penyakit pulpa dan periapikal.

\section{Wawancara}

Wawancara adalah komunikasi dua arah untuk mendapatkan data dari responden [8]. Wawancara digunakan apabila peneliti ingin mengetahui hal-hal yang lebih mendalam dari responden dan jumlah responden sedikit [9]. Dalam penelitian ini, wawancara dilakukan untuk mengetahui informasi mengenai penyakit pulpa dan periapikal serta gejala dan solusinya. Para pakar yang dijadikan nara sumber adalah dokter gigi dengan pengalaman antara 5 s.d. 7 tahun, yaitu drg. Adibah sebagai owner dan dokter spesialis gigi pada Klinik drg. Adibah, drg.

Fadhilah, et, al (Sistem Pakar Berbasis Web Menggunakan Metode Forward Chaining Untuk Mendiagnosa Penyakit Pulpa Dan Periapikal) 
Fitrianida sebagai dokter spesialis gigi pada Mydentist, dan drg. Hairiah sebagai owner dan dokter spesialis gigi pada Aziz Dental Clinic.

\section{Studi Pustaka}

Studi pustaka atau dikenal juga dengan studi dokumentasi adalah mencari data mengenai hal-hal atau variabel yang berupa catatan, transkrip, buku, surat kabar, majalah, prasasti, notulen rapat, agenda, dan lain-lain [10]. Saat ini dokumen dapat berbentuk fisik maupun digital. Dalam penelitian ini, studi pustaka dilakukan dalam menyusun landasan teori, menyusun model keputusan, dan metode penelitian melalui sumber referensi yang ada di Perpustakaan STMIK Nusa Mandiri Jakarta dan tempat lain, serta sumber-sumber online.

\subsection{Pengembangan Model Pakar}

Dalam pembuatan sistem pakar ini penulis menggunakan metode forward chaining, yaitu penalaran yang dimulai dari sekumpulan data menuju kesimpulan. Menurut Wilson dalam Kusrini [11], forward chaining berarti menggunakan himpunan aturan kondisi-aksi. Dalam metode ini, data digunakan untuk menentukan aturan mana yang akan dijalankan, kemudian aturan tersebut dijalankan. Proses diulang sampai ditemukan suatu hasil. Pada teknik forward chaining, penalaran akan dimulai dari sejumlah fakta-fakta atau data-data untuk menguji hipotesis.

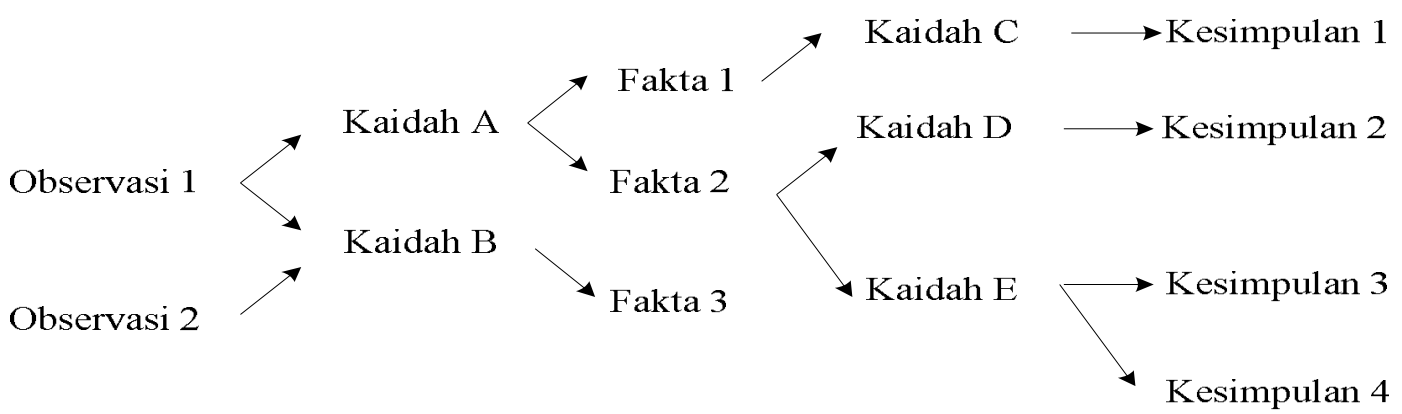

Sumber: Kusrini [11]

\section{Gambar 1. Forward Chaining}

\subsection{Model Pengembangan Sistem}

Model pengembangan sistem yang dilakukan dalam pengembangan sistem pakar ini, terdiri dari rangkaian kegiatan, sebagai berikut:

1) Analisa Kebutuhan Sistem

Pada tahap ini dilakukan asesmen terhadap pengguna untuk menggali secara detail software requirement dari pengguna.

2) Desain

Pada tahap desain dilakukan perancangan sistem, mulai dari desain arsitektur sistem, desain proses bisnis, desain database, hingga desain user interface. Alat bantu yang digunakan dalam tahap desain ini adalah Unified Modeling Language (UML) dan Entity Relationship Diagram (ERD).

3) Code Generation

Pada tahap ini dilakukan penulisan kode program dengan menggunakan bahasa PHP, sedangkan software untuk manajemen database menggunakan MySQL.

4) Testing 
Kegiatan testing dilakukan untuk meminimalisir kesalahan (error) dan untuk memastikan keluaran yang dihasilkan telah sesuai dengan user requirement dengan menggunakan metode black box testing.

\section{HASIL DAN PEMBAHASAN}

\subsection{Analisis Kebutuhan Sistem}

Berdasarkan hasil studi pustaka dan wawancara yang dilakukan pada para pakar, diketahui informasi-informasi, sebagai berikut:

1) Penyakit pulpa pada gigi dibagi menjadi 5, yaitu:
a) Hiperemiae Pulpa
b) Pulpitis Reversible
c) Pulpitis Irreversible
d) Pulpitis Hiperplastik/Pulpa Polip
e) Nekrosis Pulpa

2) Penyakit periapikal pada gigi dibagi menjadi 7 , yaitu:
a) Periodontitis Apikalis Simpomatik
b) Periodontitis Apikalis Asimptomatik
c) Abses Apikalis Akut
d) Abses Apikalis Kronis
e) Abses Dento Alveolar
f) Abses Periodontal
g) Kista Periapikal

3) Penyebab dan gejala pulpa pada gigi dan cara terapi, sebagai berikut:
a) Nama penyakit
Hiperemia Pulpa

Penyebab

Bakteri pada gigi berlubang

Gejala

Sakit spontan, linu dengan makanan manis, linu dengan

b) Nama penyakit suhu dingin.

Penyebab

\section{Pulpitis Reversible}

Gejala

Bakteri pada gigi berlubang hampir mengenai pulpa.

c) Nama penyakit

Sakit tajam karena makanan minuman dingin dan sakit tajam karena udara dingin, tidak ada sakit spontan.

Penyebab

Pulpitis Irreversible

Gejala

Bakteri pada gigi berlubang sudah menembus pulpa.

Nama penyakit

Sakit spontan, nyeri lama, berdenyut, mengganggu tidur malam, sakit kepala, sakit pelipis.

Penyebab Pulpitis Hiperplastik/Pulpa Polip

Iritasi pada pulpa oleh bakteri secara terus menerus hingga menimbulkan tumbuhnya jaringan seperti bisul didalam gigi.

Gejala

Sakit spontan, sakit terhadap stimulus panas dan dingin, sakit saat mengunyah.

e) Nama penyakit Nekrosis Pulpa

Penyebab

Bakteri pada gigi berlubang yang sudah terlalu lama meyebabkan kematian pulpa. 
Gejala

f) Nama penyakit Penyebab

Gejala

g) Nama penyakit

Penyebab

Gejala

h) Nama penyakit

Penyebab

Gejala

i) Nama penyakit

Penyebab

Gejala

j) Nama penyakit

Penyebab

Gejala

k) Nama penyakit

Penyebab

Gejala

1) Nama penyakit

Penyebab

Gejala
Sakit terhadap stimulus panas dan dingin, sakit spontan, sakit pelipis atau telinga, bau busuk, rasa tidak nyaman saaat makanan masuk ke mulut, gigi berubah warna dari abu-abu sampai agak kehitaman.

Periodontitis Apikalis Simptomatik

Bakteri plak yang masuk ke dalam jaringan periodontal.

Sakit menetap, gigi terasa lebih panjang dari gigi lainnya, sakit saat menggigit, sedikit goyang.

Periodontitis Apikalis Asimptomatik

Bakteri plak yang masuk ke dalam jaringan periodontal.

Tidak bisa merasakan dingin, gigi sakit bila diketuk.

Abses Apikalis Akut

Bakteri plak yang masuk ke dalam jaringan periodontal.

Pembengkakan difus atau meluas pada gusi, demam bila bengkak meluas, gigi yang bersentuhan akan sakit, sedikit goyang.

Abses Apikalis Kronis

Bakteri.

Bengkak pada gusi, sinus drainase

Abses Periodontal

Infeksi gusi.

Gigi goyang, terjadi kehilangan penyangga gigi.

Abses Alveolar

Infeksi gusi.

Sakit gigi, sakit saat mengunyah, demam disertai pembengkakan kelenjar getah bening di leher, gigi goyang, banyak kehilangan tulang, kehilangan penyangga, infeksi gusi.

Kista Periapikal

Bakteri pada infeksi pulpa.

Tidak ada gejala, tidak nyaman bila dipakai saat mengunyah, sedikit goyang.

Berdasarkan pengetahuan di atas, guna sebagai acuan dalam membuat pohon keputusan dan kaidah yang digunakan dalam merancang sistem pakar, maka gejala pada penyakit pulpa dan periapikal dapat disusun ke dalam Tabel 1 sebagai berikut:

Tabel 1. Gejala

\begin{tabular}{ll}
$\begin{array}{c}\text { Kode } \\
\text { Gejala }\end{array}$ & \multicolumn{1}{c}{ Gejala } \\
\hline G001 & Sakit spontan \\
\hline G002 & Linu dengan udara dingin \\
\hline G003 & Linu dengan makanan manis \\
\hline G004 & Sakit tajam karena makanan dan minuman dingin \\
\hline G005 & Nyeri lama \\
\hline G006 & Berdenyut \\
\hline
\end{tabular}

Fadhilah, et, al (Sistem Pakar Berbasis Web Menggunakan Metode Forward Chaining Untuk Mendiagnosa Penyakit Pulpa Dan Periapikal) 


\begin{tabular}{ll}
\hline G007 & Mengganggu tidur malam \\
\hline G008 & Sakit kepala \\
\hline G009 & Sakit pelipis \\
\hline G010 & Sakit terhadap stimulus panas dan dingin \\
\hline G011 & Sakit saat mengunyah \\
\hline G012 & Bau busuk \\
\hline G013 & Rasa tidak nyaman ketika makanan masuk kemulut \\
\hline G014 & Gigi berubah warna dari abu-abu sampai kehitaman \\
\hline G015 & Sakit menetap \\
\hline G016 & Gigi terasa lebih panjang dari gigi lainnya \\
\hline G017 & Sakit saat menggigit \\
\hline G019 & Sedikit goyang \\
\hline G020 & Gidak bisa merasakan dingin \\
\hline G021 & Gusi bengkak \\
\hline G022 & Pembengkakan difus/menyebar \\
\hline G023 & Demam bila bengkak meluas \\
\hline G024 & Gigi yang bersentuhan terasa sakit \\
\hline G025 & Adanya sinus drainase \\
\hline G026 & Gigi goyang \\
\hline G027 & Banyak kehilangan tulang \\
\hline G028 & Infeksi gusi \\
\hline G029 & Demam disertai pembengkakan kelenjar getah bening \\
\hline G030 & Kehilangan penyangga \\
\hline
\end{tabular}
berikut:

Sementara tabel pakar dari sistem pakar dapat digambarkan pada Tabel 2, sebagai

Tabel 2. Pakar

\begin{tabular}{|c|c|c|c|c|c|c|c|c|c|c|c|c|c|c|c|c|c|c|c|c|c|c|c|c|c|c|c|c|c|c|c|}
\hline RULE & \&े & $\begin{array}{l}\text { Oे } \\
\text { Oे }\end{array}$ & 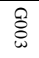 & $\begin{array}{l}\text { Q } \\
\text { Oे } \\
+\end{array}$ & $\begin{array}{l}\text { Q } \\
\text { ò } \\
\text { ơ }\end{array}$ & @े & 高 & 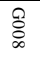 & 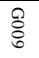 & $\frac{9}{0}$ & $\stackrel{9}{\rho}$ & $\frac{Q}{\circ}$ & $\underset{\omega}{\stackrel{\rho}{0}}$ & $\stackrel{9}{\stackrel{9}{+}}$ & $\frac{Q}{8}$ & $\frac{Q}{\circ}$ & $\stackrel{8}{8}$ & $\underset{\infty}{\stackrel{Q}{\infty}}$ & $\frac{9}{6}$ & 总 & 㣽 & 总 & 总 & $\begin{array}{l}\text { Oे } \\
\text { 品 }\end{array}$ & 总 & 商 & 总 & $\begin{array}{l}\text { 怘 } \\
\text { 嗢 }\end{array}$ & 㣽 & $\begin{array}{l}\text { 总 } \\
\text { ô }\end{array}$ & KESIMPULAN \\
\hline P001 & $\mathrm{x}$ & $\mathrm{X}$ & $\mathrm{x}$ & & & & & & & & & & & & & & & & & & & & & & & & & & & & $\mathrm{AA}$ \\
\hline P002 & & $\mathrm{X}$ & & $\mathrm{X}$ & & & & & & & & & & & & & & & & & & & & & & & & & & & BB \\
\hline P003 & $\mathrm{X}$ & & & & $\mathrm{X}$ & $\mathrm{X}$ & $\mathrm{X}$ & $\mathrm{X}$ & $\mathrm{X}$ & & & & & & & & & & & & & & & & & & & & & & CC \\
\hline P004 & $\mathrm{X}$ & & & & & & & & & $\mathrm{X}$ & $\mathrm{x}$ & & & & & & & & & & & & & & & & & & & & DD \\
\hline P005 & $\mathrm{X}$ & & & & & & & & $\mathrm{x}$ & $\mathrm{x}$ & & $\mathrm{x}$ & $\mathrm{x}$ & $\mathrm{X}$ & & & & & & & & & & & & & & & & & EE \\
\hline P006 & & & & & & & & & & & & & & & $\mathrm{X}$ & $\mathrm{x}$ & $\mathrm{X}$ & $\mathrm{x}$ & & & & & & & & & & & & & $\mathrm{FF}$ \\
\hline P007 & & & & & & & & & & & & & & & & & & & $\mathrm{x}$ & $\mathrm{x}$ & & & & & & & & & & & GG \\
\hline P008 & & & & & & & & & & & & & & & & & & $\mathrm{x}$ & & & & $\mathrm{x}$ & $\mathrm{X}$ & $\mathrm{X}$ & & & & & & & $\mathrm{HH}$ \\
\hline P009 & & & & & & & & & & & & & & & & & & & & & & $\mathrm{x}$ & & & $\mathrm{X}$ & & & & & & II \\
\hline $\mathrm{P} 010$ & & & & & & & & & & & & & & & & & & & & & & & & & & & $\mathrm{X}$ & & & $\mathrm{x}$ & $\mathrm{JJ}$ \\
\hline P011 & & & & & & & & & & & & $\mathrm{x}$ & & & & & & & & & & & & & & $\mathrm{x}$ & $\mathrm{X}$ & $\mathrm{x}$ & $\mathrm{X}$ & $\mathrm{x}$ & KK \\
\hline P012 & & & & & & & & & & & $\mathrm{x}$ & & & & & & & $\mathrm{x}$ & & & & & & & & & & & & & LL \\
\hline
\end{tabular}

Rule 1 Jika sakit gigi spontan dan linu makanan manis dan linu dengan suhu dingin, maka didiagnosa mengalami sakit Hiperemia Pulpa.

Rule 2 Jika sakit gigi terasa sampai tajam kearena makanan minum dingin dan sakit tajam karena udara dingin dan tidak ada sakit spontan, maka didiagnosa mengalami sakit Pulpitis Reversible.

Rule 3 Jika sakit spontan dan nyeri lama dan gigi berdenyut serta mengganggu tidur malam dan sakit kepala dan pelipis, maka didiagnosa mengalami sakit Pulpitis Irreversible. 
Rule 4 Jika sakit spontan dan sakit terhadap stimulus panas dan dingin dan sakit bila dipakai mengunyah, maka didiagnosa mengalami sakit Pulpitis Hiperplastik/Pulpa Polip.

Rule 5 Jika sakit terhadap stimulus panas dan dingin dan sakit spontan dan sakit pelipis atau telinga dan bau busuk dan rasa tidak nyaman saaat makanan masuk ke mulut dan gigi berubah warna dari abu-abu sampai agak kehitaman, maka didiagnosa mengalami sakit Nekrosis Pulpa.

Rule 6 Jika sakit menetap dan gigi terasa lebih panjang dari gigi lainnya dan sakit saat menggigit dan sedikit goyang, maka didiagnosa mengalami sakit Perodentitis Apikalis Simptomatik.

Rule 7 Jika tidak bisa merasakan dingin dan gigi sakit bila diketuk, maka didiagnosa mengalami sakit Perodentitis Apikalis Asimptomatik.

Rule 8 Jika ada pembengkakan difus atau meluas pada gusi dan demam bila bengkak meluas dan gigi yang bersentuhan akan sakit dan gigi sedikit goyang, maka didiagnosa mengalami sakit Abses Apikalis Akut.

Rule 9 Jika bengkak pada gusi dan sinus drainase, maka didiagnosa mengalami sakit Abses Apikalis Kronis.

Rule 10Jika gigi anda goyang dan banyak kehilangan jaringan penyangga gigi, maka didiagnosa mengalami sakit Abses Periodontal.

Rule 11Jika sakit gigi dan anda merasa sakit saat mengunyah dan demam disertai pembengkakan kelenjar getah bening di leher dan gigi goyang, banyak kehilangan tulang dan kehilangan penyangga, infeksi gusi, maka didiagnosa mengalami sakit Abses Dento Alveolar.

Rule 12Jika anda tidak merasa ada gejala dan gigi anda tidak nyaman saat mengunyah dan sedikit goyang, maka didiagnosa mengalami sakit Kista Periapikal.

Berdasarkan uraian di atas, maka dirancang pohon keputusan untuk digunakan untuk menentukan pencarian fakta. Suatu pohon adalah hierarki struktur yang terdiri dari node (simpul) yang menyimpan informasi atau pengetahuan dan cabang yang menghubungkan node. Pohon keputusan pakar ini menggunakan metode forward chaining yang artinya perkumpulan fakta-fakta yang menyudut atau menghasilkan kesimpulan. 


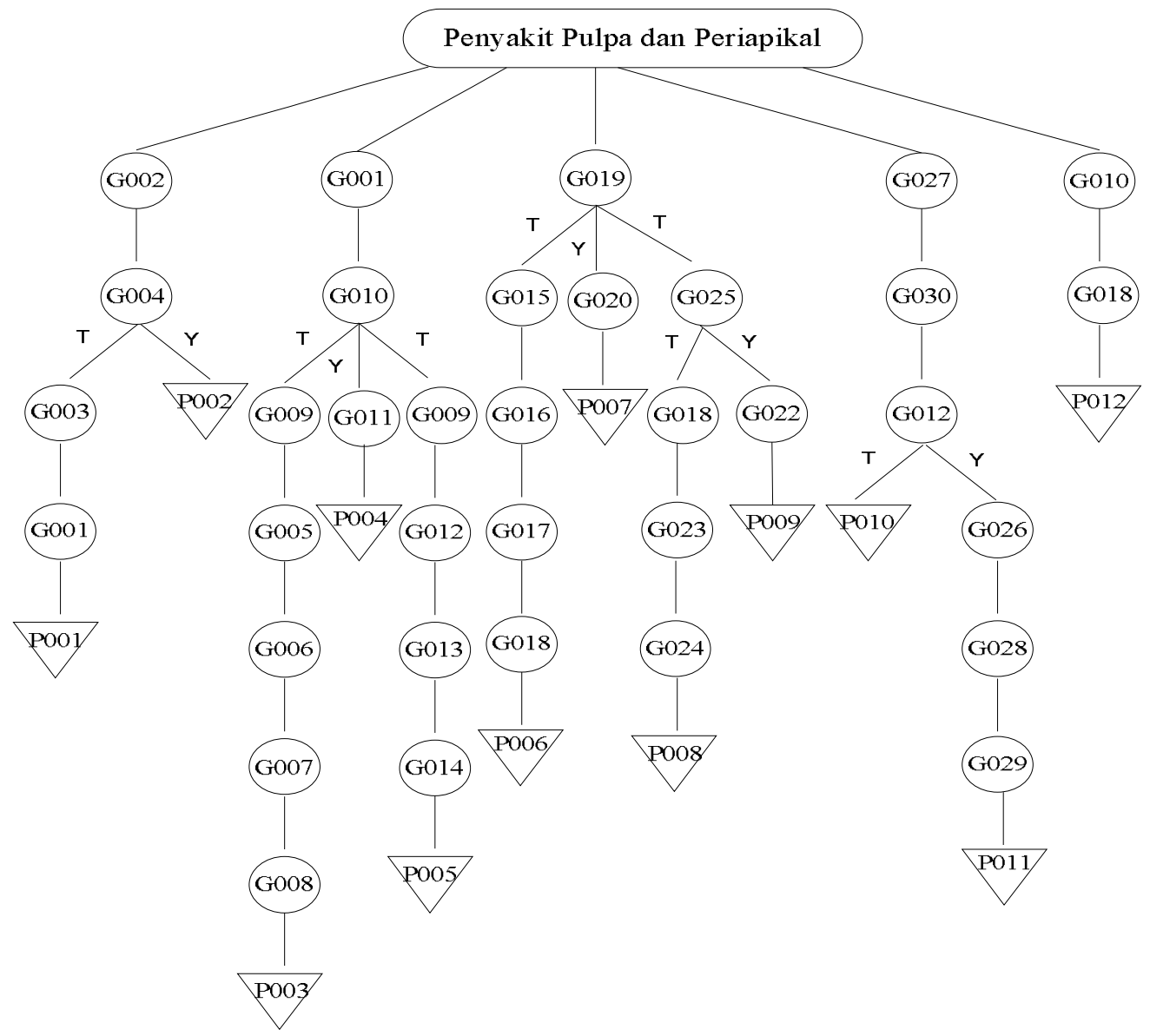

Gambar 2. Pohon Keputusan

Keterangan GEJALA

G001 :Sakit spontan

G002 :Linu dengan udara dingin

G003 :Linu degan makanan manis

Keterangan RULE

P01 :Hiperemia Pulpa

Keterangan SOLUSI

AA :Jaringan karies dibersihkan dahulu kemudian dilakukan pulp capping untuk merangsang pembentukan dentin tersier kemudian ditambal tetap.

Keterangan GEJALA

G002 :Linu dengan udara dingin

G004 :Sakit tajam karena makanan dan minuman dingin

Keterangan RULE

P02 :Pulpitis Reversible

Keterangan SOLUSI

BB :Dengan melakukan penghilangan stimulasi (jejas) sudah cukup, bila gejala hilang gigi harus dites untuk memastikan ada atau tidanya nekrosis kemudian dilakukan penambalan berlapis (sandwich technique)

Keterangan GEJALA

G001 :Sakit spontan

G005 : Nyeri lama

G006 : Berdenyut

Fadhilah, et, al (Sistem Pakar Berbasis Web Menggunakan Metode Forward Chaining Untuk Mendiagnosa Penyakit Pulpa Dan Periapikal) 
G007 : Mengganggu tidur malam

G008 : Sakit kepala

G009 : Sakit pelipis

Keterangan RULE

P03 : Pulpitis Irreversible

Keterangan SOLUSI

CC :Melakukan root canal treatment (pulpektomi) bila sudah tidak ada gejala pasien datang berkunjung 3-4 kali kemudian dilakukan penambalan tetap.

Keterangan GEJALA

G001 : Sakit spontan

G010 : Sakit terhadap stimulus atau rangsangan panas dan dingin

G011 : Sakit saat mengunyah

Keterangan RULE

P04 : Pulpitis Hiperplastik/Pulpa Polip

Keterangan SOLUSI

DD :Dilakukannya pemotongan hiperplastik kemudian root canal treatment (pulpektomi) bila sudah tidak ada gejala dalam 3-4 kali kemudian dilakukan penambalan tetap.

Keterangan GEJALA

G001 : Sakit spontan

G009 : Sakit pelipis

G010 : Sakit terhadap stimulus atau rangsangan panas dan dingin

G012 : Bau busuk

G013 : Rasa tidak nyaman ketika makanan masuk ke mulut

G014 : Gigi berubah warna dari abu-abu sampai kehitaman

Keterangan RULE:

P05 :Nekrosis Pulpa

Keterangan SOLUSI:

EE :Agar pasien sembuh dari gejala harus dilakukan root canal treatment atau pulpektomi selama 4-5 kali kunjungan, kemudian dilakukannya penambalan tetap.

Keterangan GEJALA

G015 : Sakit menetap

G016 : Gigi terasa lebih panjang dari gigi lainnya

G017 : Sakit saat menggigit

G018 : Sedikit goyang

Keterangan RULE

P06 :Periodontitis Apikalis Simptomatik

Keterangan SOLUSI

FF : Dilakukan root canal treatment atau pulpektomi atau perawatan saluran akar.

Keterangan GEJALA

G019 : Gigi tidak bisa merasakan dingin

G020 : Gigi sakit bila diketuk

Keterangan RULE

P07 :Periodontitis Apikalis Asimptomatik

Keterangan SOLUSI

GG : Dilakukan root canal treatment atau pulpektomi atau perawatan saluran akar.

Keterangan GEJALA

G018 : Sedikit Goyang

G022 : Pembengkakan difus / pembengkakan menyebar

G023 : Demam bila bengkak

G024 : Gigi yang bersentuhan terasa sakit

Fadhilah, et, al (Sistem Pakar Berbasis Web Menggunakan Metode Forward Chaining Untuk Mendiagnosa Penyakit Pulpa Dan Periapikal) 


\section{Keterangan RULE}

P08 : Abses Apikal Akut

Keterangan SOLUSI

HH : Minum obat amoxcilin $3 \times 1$ hari, postan $3 \times 1$ hari, dexa methason $3 \times 1$ hari. Bila bengkak terlalu besar \&goyangnya parah, jika setelah obat habis dan sudah kempes, gigi dicabut.

Keterangan GEJALA

G022 : Pembengkakan difus / pembengkakan menyebar

G025 : Adanya sinus drainase

Keterangan RULE

P09 : Abses Apikal Kronis

Keterangan SOLUSI

II : Dengan melakukan drainase, bila bengkak ada "matanya/fistula" ditusuk agar nanahnya keluar. Minum obat amoxicilin 3x1 hari, postan 3x1 hari, dexa methason $3 \times 1$ hari, bila telah sembuh dilakukan pulektomi kemudian drainase saluran abses melalui gigi.

Keterangan GEJALA

G011 : Sakit saat mengunyah

G026 : Gigi goyang

G027 : Banyak kehilangan tulang

G028 : Infeksi gusi

G029 : Demam disertai pembengkakan kelenjar getah bening

G030 : Kehilangan penyangga

Keterangan RULE

P10 : Abses Periodontal

Keterangan SOLUSI

JJ : Dengan cara melakukan drainase abses dan kuretase gingiva.

Keterangan GEJALA

G026 : Gigi goyang

G030 : Kehilangan penyangga gigi

Keterangan RULE

P11 :Abses Dento Alveoral

Keterangan SOLUSI

KK : bila dari hasil rontgen terihat radolusen berbatas difus periapical, kemudian minum obat antibiotic selama beberapa hari untuk merdakan infeksi samapi sakitnya berkurang kemudian gigi harus dicabut.

Keterangan GEJALA

G011 : Sakit saat mengunyah

G018 : Sedikit goyang

Keterangan RULE

P12 : Kista Periapikal

Keterangan SOLUSI

LL : Dapat dilakukan Root canal treatment atau pulpektomi, dapat juga dilakukan perawatan saraf gigi (endodontic) dan dapat dilakukan juga pengambilan kista.

\subsection{Rancangan Sistem Usulan}

1) Rancangan Algoritma

Fadhilah, et, al (Sistem Pakar Berbasis Web Menggunakan Metode Forward Chaining Untuk Mendiagnosa Penyakit Pulpa Dan Periapikal) 


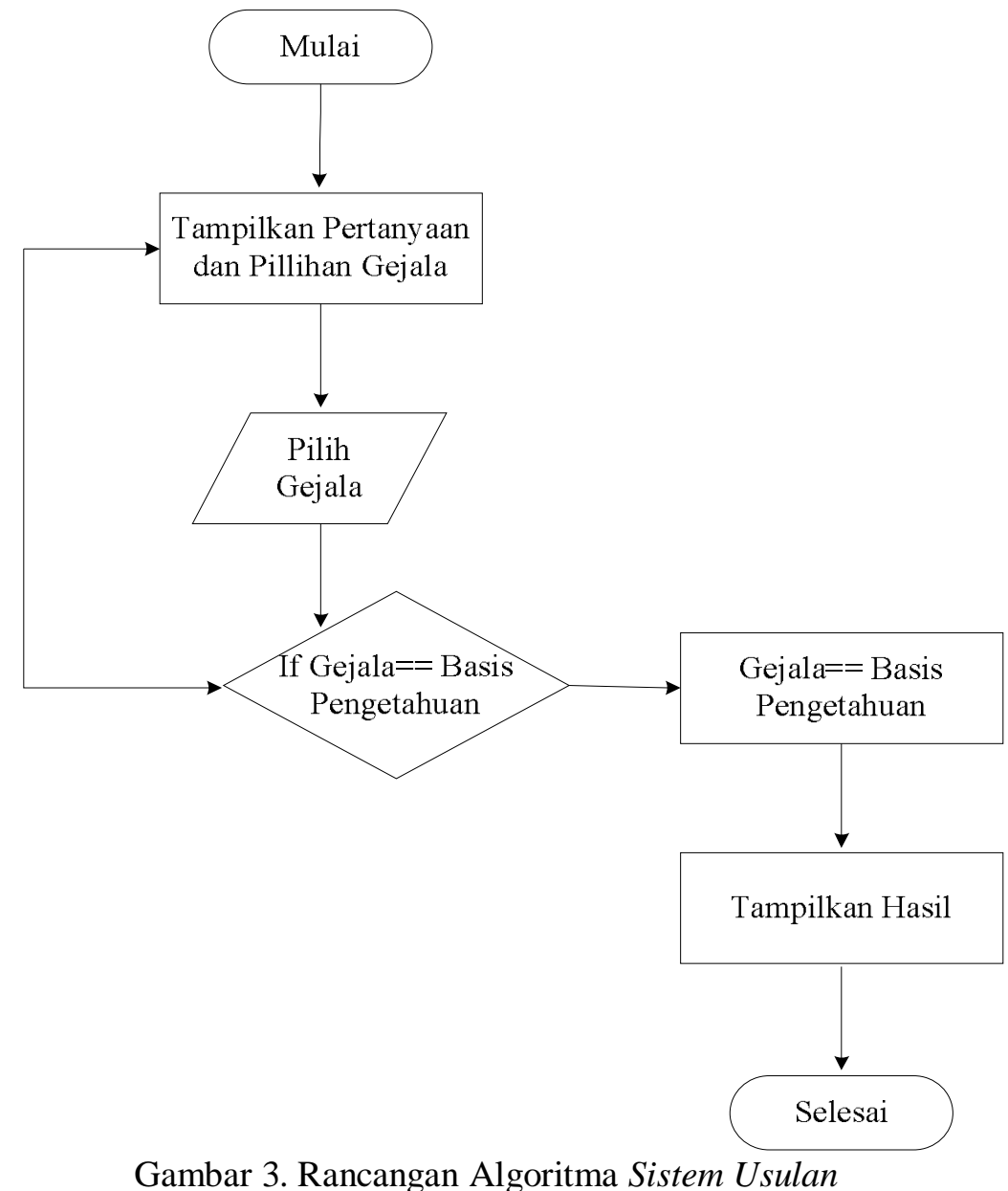

Proses diagnosa penyakit pulpa dan periapikal ini dimulai dengan masyarakat pengguna mengakses aplikasi web sistem pakar. Kemudian sistem pakar akan menampilkan pertanyaan dan pilihan gejala yang dapat dipilih oleh masyarakat pengguna. Berdasarkan pilihan jawaban yang disampaikan oleh masyarakat pengguna, sistem pakar akan menyesuaikan dengan basis pengetahuan yang telah disimpan di dalam database. Terakhir, sistem pakar akan menyampaikan informasi mengenai hasil dari diagnosis mengenai jenis penyakit pulpa dan periapikal yang dialami beserta solusi penanganan yang bisa dilakukan oleh masyarakat pengguna.

\section{2) Pemodelan Sistem Usulan}

Berikut ini spesifikasi sistem pakar yang diusulkan:

Halaman Administrasi

B1. Admin dapat mengelola data artikel

B2. Admin dapat mengelola data gejala.

B3. Admin dapat mengelola solusi.

B4. Admin dapat mengelola rule.

B5. Admin dapat melihat data tamu.

B6. Admin dapat mengelola admin.

B7. Admin dapat melihat dan mencetak data laporan gejala, laporan diagnosa dan laporan solusi. 
Halaman User

A1. User masuk ke halaman home

A2. User registrasi sebelum melakukan konsultasi

A3. User dapat melihat artikel

A4. User dapat mengisi buku tamu

Spesifikasi halaman user di atas, dapat digambarkan menggunakan usecase diagram sebagai berikut:

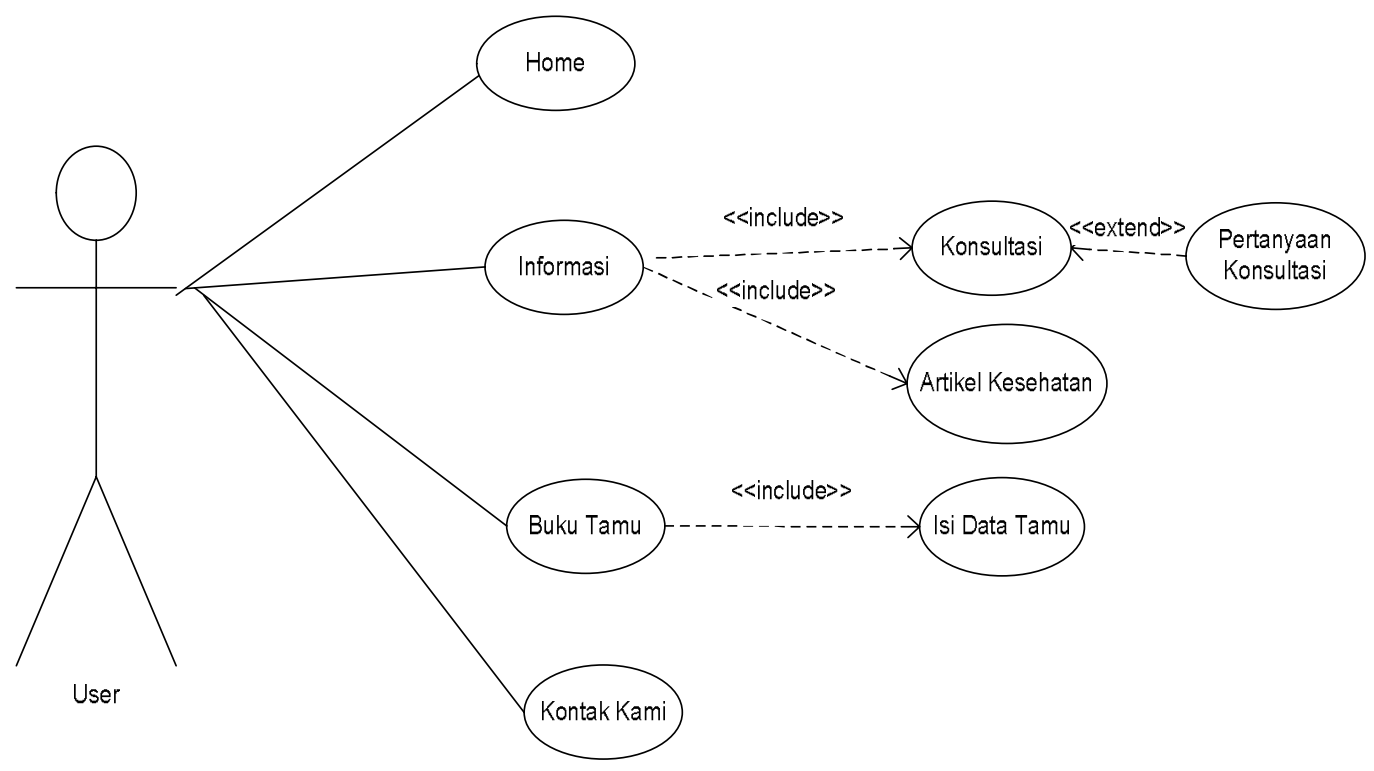

Gambar 4. Usecase Halaman User Sistem Usulan

Berdasarkan pemodelan yang digambarkan melalui usecase diagram, dapat digambarkan proses bisnis yang dilakukan oleh user (masyarakat) melalui activity diagram, sebagai berikut: 


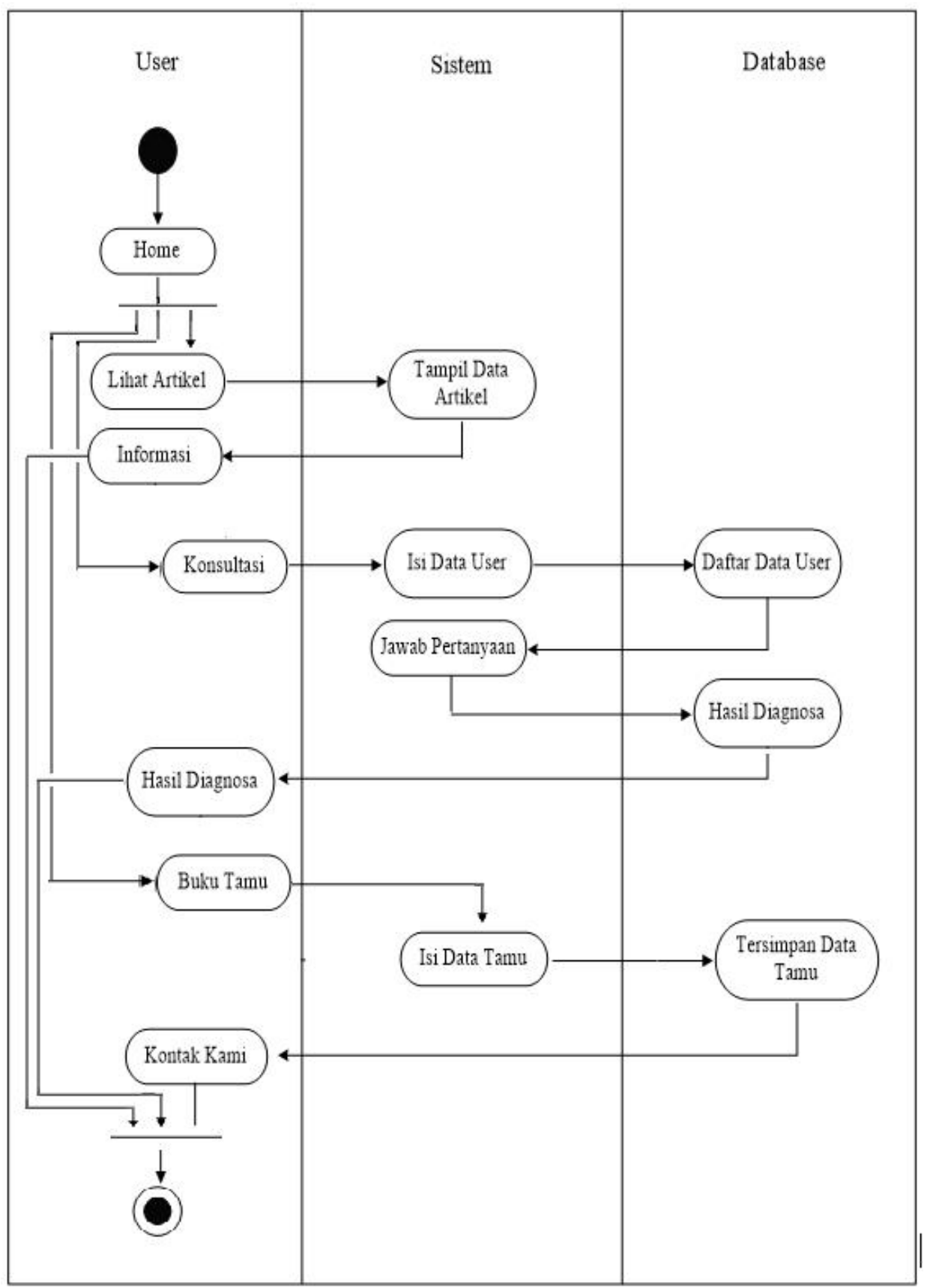

Gambar 5. Activity Diagram Sistem Usulan

User atau masyarakat pengguna mengakses halaman utama website, kemudian user dapat melihat informasi mengenai penyakit pulpa dan periapikal melalui halaman artikel kesehatan. Selain itu, user juga dapat melakukan konsultasi untuk mendiagnosa penyakit pulpa dan periapikal yang dialami dengan menjawab pertanyaan-pertanyaan yang disampaikan oleh sistem mengenai gejala-gejala yang dialami. Berdasarkan jawaban yang diberikan oleh user, sistem akan menyampaikan hasil diagnosa yang dilakukan berdasarkan basis pengetahuan yang telah ditentukan pada sistem pakar. Kemudian user juga dapat mengisi buku tamu dan melihat daftar kontak. 


\section{3) Entity Relationship Diagram}

EntityRelationship Diagram (ERD) adalah pemodelan awal basis data yang dikembangkan berdasarkan teori himpunan dalam bidang matematika. ERD digunakan untuk pemodelan basis data relasional [12].

ERD pada sistem pakar ini dapat Digambar melalui Gambar 6, sebagai berikut:

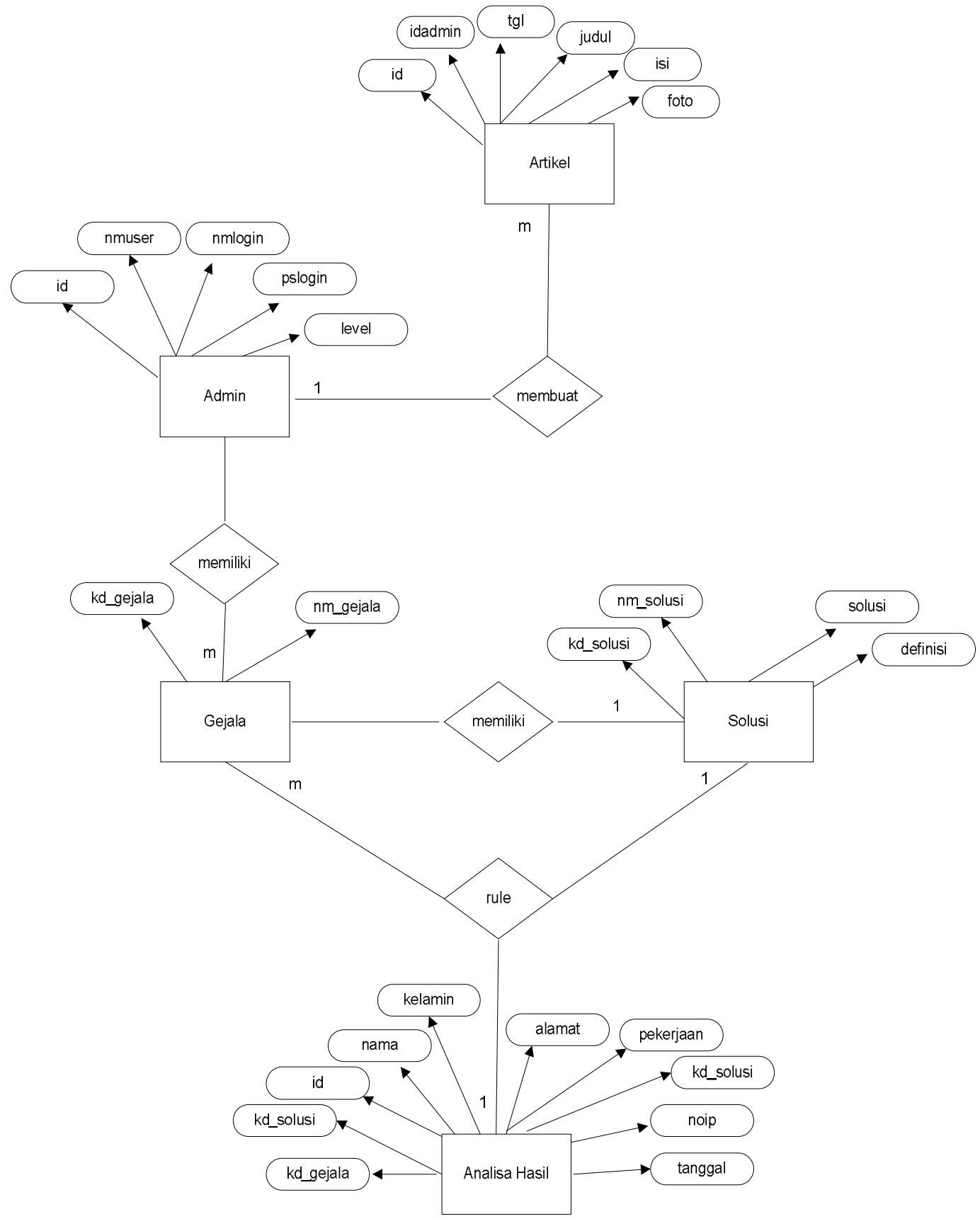

4) Desain Interface

Gambar 6. ERD Sistem Usulan

a) Halaman Utama

Fadhilah, et, al (Sistem Pakar Berbasis Web Menggunakan Metode Forward Chaining Untuk Mendiagnosa Penyakit Pulpa Dan Periapikal) 


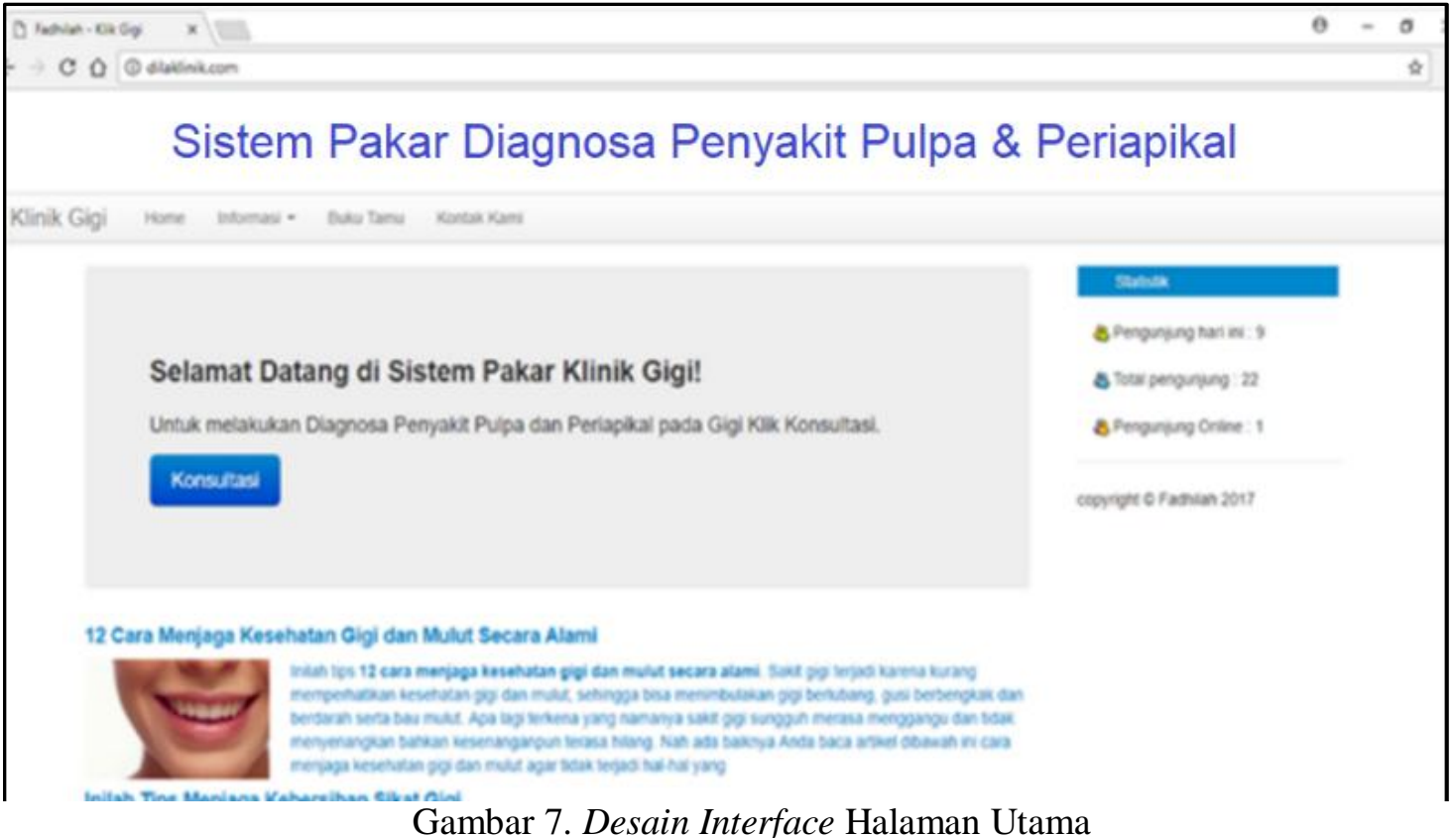

b) Halaman Konsultasi

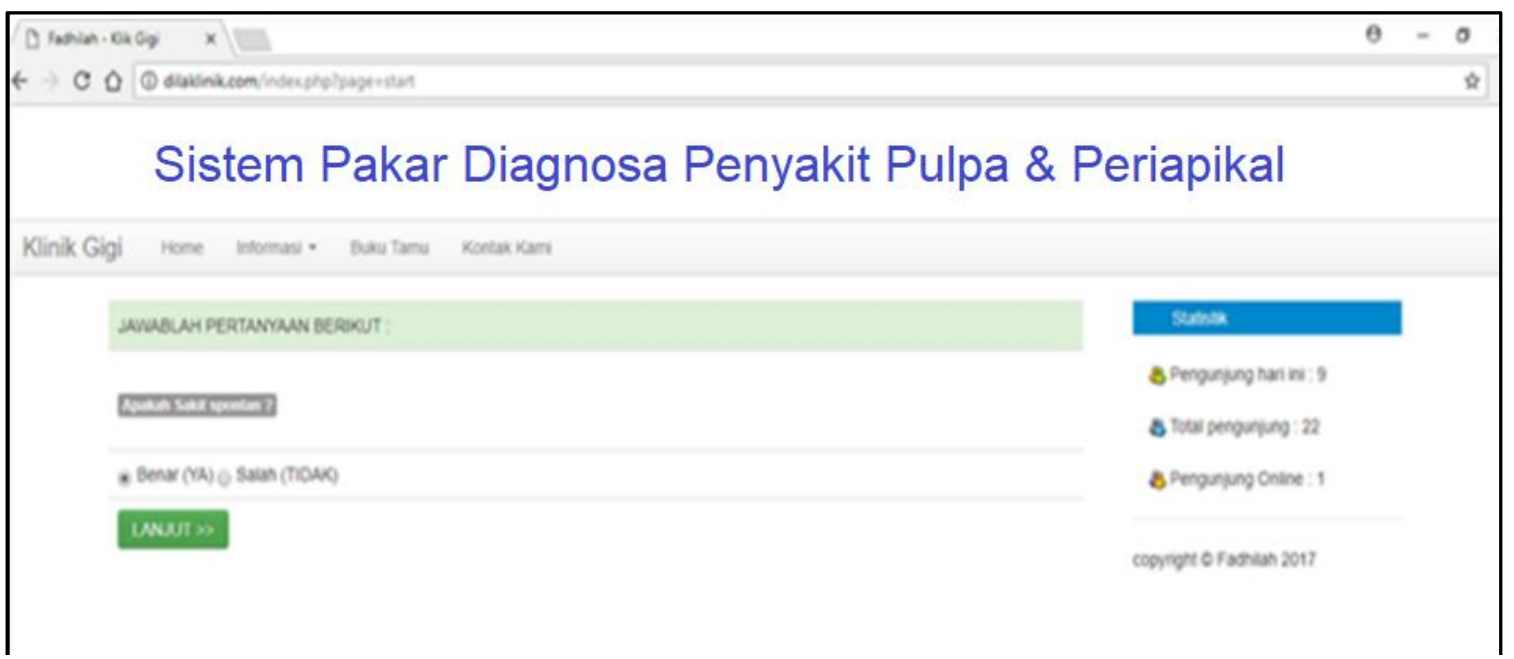

Gambar 8. Desain Interface Halaman Konsultasi

\section{KESIMPULAN}

Berdasarkan penelitian yang telah dilakukan, dapat ditarik beberapa kesimpulan, sebagai berikut:

1) Metode forward chaining dapat digunakan untuk membangun sistem pakar untuk mendiagnosa penyakit pulpa dan periapikal.

2) Aplikasi sistem pakar diagnosa penyakit pulpa dan periapikal ini dapat membantu masyarakat pengguna dalam mendiagnosa penyakit pulpa dan periapikal berdasarkan gejalagejala yang dialaminya. 
3) Aplikasi ini disajikan secara online, sehingga dapat dengan mudah diakses oleh masyarakat untuk mengetahui informasi mengenai jenis dan solusi dari jenis penyakit pulpa dan periapikal yang dialaminya.

\section{SARAN}

Berdasarkan penelitian yang telah dilakukan, disampaikan beberapa saran untuk pengembangan pada penelitian selanjutnya, sebagai berikut:

1) Pengetahuan mengenai penyakit pulpa dan periapikal terus berkembang, sehingga ke depan sangat dimungkinkan untuk melakukan pengembangan dan pendalaman pembahasannya.

2) Seiring dengan perkembangan aplikasi mobile, sehingga ke depan sangat dimungkinkan untuk melakukan pengembangan sistem pakar ini dalam bentuk aplikasi mobile.

\section{UCAPAN TERIMA KASIH}

Penulis mengucapkan terima kasih kepada nara sumber, yaitu drg. Adibah pada klinik drg. Adibah, drg. Fitrianida pada Mydentist, dan drg. Hairiah pada Aziz Dental Clinic yang telah memberi dukungan terhadap penelitian ini.

\section{DAFTAR PUSTAKA}

[1] Efita, Reni. 2016, Penyakit Gigi \& Mulut: Kasus Tertinggi Keenam di Indonesia, Tersedia pada: https://lifestyle.bisnis.com/read/20160324/106/531288/penyakit-gigimulut-kasus-tertinggi-keenam-di-indonesia, Diakses Tanggal 20 Juni 2018.

[2] Kementerian Kesehatan RI. 2013, Situasi Gigi dan Mulut di Indonesia, Kementerian Kesehatan Republik Indonesia, Jakarta.

[3] Perdana, Aretyo Jevon. 2018, Jelang Riskesdas 2018PDGI Ungkap Kerusakan Gigi di Indonesia, Tersedia pada: https://www.liputan6.com/health/read/3241884/jelangriskesdas-2018-pdgi-ungkap-kerusakan-gigi-di-indonesia, Diakses Tanggal 20 Juni 2018.

[4] Kementerian Kesehatan RI. 2012, Profil Kesehatan Indonesia Tahun 2011, Kementerian Kesehatan Republik Indonesia, Jakarta.

[5] Nurzaman, Dini Destiani, Dhami Johar Dhamiri. 2012, Pembangunan Aplikasi Sistem Pakar untuk Diagnosis Penyakit Gigi dan Mulut Pada Manusia, Jurnal Algoritma, Vol. 09 ,No. 12, hal. 1-8.

[6] Nurlaela, Fetty. 2013, Sistem Pakar untuk Mendeteksi Penyakit Gigi pada Manusia, Jurnal Speed, Volume 10, No 4, hal. 26-31.

[7] Nurlaela, Fetty. 2013, Sistem Pakar untuk Mendeteksi Penyakit Gigi pada Manusia, Jurnal Speed, Volume 10, No 4, hal. 26-31.

[8] Jogiyanto. 2008, Metodologi Penelitian Sistem Informasi, Andi, Yogyakarta.

Fadhilah, et, al (Sistem Pakar Berbasis Web Menggunakan Metode Forward Chaining Untuk Mendiagnosa Penyakit Pulpa Dan Periapikal) 
[9] Sugiyono. 2014, Metode Penelitian Bisnis (Pendekatan Kuantitatif, Kualitatif, dan R\&D), Alfabeta, Bandung.

[10] Arikunto, Suharsimi. 2013, Prosedur Penelitian Suatu Pendekatan Praktik, Rineka Cipta, Jakarta.

[11] Kusrini. 2008, Aplikasi Sistem Pakar, Andi Offset, Jakarta.

[12] Rosa dan Shalahuddin. 2013, Rekayasa Perangkat Lunak, Informatika, Bandung. 